\title{
Research on the Innovation of Higher Vocational Education
}

\author{
Ping Liu \\ Liaoning Jianzhu Vocational College, Liaoyang, Liaoning, 111000
}

\begin{abstract}
Keywords: Vocational Education, Innovation Research, Education Content
\end{abstract}
\begin{abstract}
Higher vocational colleges in the scale of higher education in China has accounted for "half of the country", become an important part of China's higher education. At present, innovative education for the purpose of cultivating students' innovative spirit and autonomous learning ability has put forward a series of reform requirements for the existing educational concepts, management system, operation mechanism and teaching methods for the purpose of teaching existing knowledge. This determines the vocational colleges must promptly change the mode of personnel training, change and innovation teaching management, to adapt to the overall promotion of quality education, training creative talent needs. As a basic activity and a central part of the management of higher vocational colleges, teaching management plays an important role and role in the school. It is the basis for the normal operation of teaching activities and an important guarantee for improving the quality of teaching. At present, the teaching management of higher vocational colleges is in a progressive stage of development.
\end{abstract}

\section{Introduction}

It is an important part of the higher education system, especially the higher vocational school, which is rich in educational level and flexible in running mechanism. It has rich connotation in teaching organization form, institution setting category, organization development and historical evolution. Education and economic and social development are closely related, by the world's governments and the education sector attaches great importance. In recent years, with the transformation of higher education from "elite education" to "popular education", higher education has achieved leapfrog development, and the contribution of higher vocational colleges has made great contributions. As of the end of 2009, China's higher vocational colleges have 1215, more than 1090 undergraduate colleges, vocational (specialist) full-time students in the average size of 9086 people. 1 and basically formed every city (land) at least set up a higher vocational school pattern, with the local economic and social development and the people's interests the most direct and most closely related institutions of higher education. It can be said that higher vocational colleges in China's higher education scale has accounted for "half of the country", become an important part of China's higher education. The rapid growth of the number of students in vocational colleges not only provides a new opportunity for the development of higher education in our country, but also brings great pressure to the teaching and personnel training of higher vocational education. Different from the ordinary higher education institutions to cultivate research talents as the goal, higher vocational colleges in the personnel training objectives are more focused on the actual needs of society, training high-tech applied talents. At present, innovative education for the purpose of cultivating students' innovative spirit and autonomous learning ability has put forward a series of reform requirements for the existing educational concepts, management system, operation mechanism and teaching methods for the purpose of teaching existing knowledge. This determines the vocational colleges must promptly change the mode of personnel training, change and innovation teaching management, to adapt to the overall promotion of quality education, training creative talent needs. 


\section{The content of teaching management in higher vocational colleges}

Teaching plan is an important document to ensure the quality of teaching and personnel training. It is the basic basis for organizing teaching activities, arranging teaching tasks and ensuring teaching preparation. Teaching plan is under the guidance of the Ministry of Education under the auspices of the Ministry of Education, which is organized by experts from various schools. It must conform to the laws of education and maintain certain stability. Higher vocational college teaching plan is developed by professional is to ensure the quality of teaching the basic teaching documents. The core work of the teaching plan management is to design a blueprint for the cultivation of talents, which requires us to devote a great deal of energy to the necessary and necessary basic investigation and research. This research includes the reform and development of the same and similar disciplines at home and abroad, especially the new educational concept, the new teaching content and curriculum system, teaching links and personnel training mode and so on. To organize the academic disciplines of academic disciplines and experienced teachers to study the curriculum structure of the system, only the design and construction of a whole structure of the curriculum system optimization, the overall design of the blueprint for personnel training clear, can be prepared accordingly High quality qualified graduates. Of course, the teaching plan in the development of the future but also a strict organization and implementation, teaching plan is not only a blueprint for design can be arbitrary. Its content and requirements reflect the characteristics of personnel training specifications and models.

Teaching management is mainly around the implementation of the teaching plan carried out by the teaching process and related auxiliary work organization and management. Its purpose is to organize the implementation of teaching plans and to ensure the normal operation of school teaching. The teaching process is essentially a process of cognition of students under the guidance of teachers, and a unified process of students' all-round development through teaching. Teaching operation and management of the key is to do the following two aspects: First, classroom teaching (including theoretical teaching and practical teaching) management; Second, daily teaching administration, that is, educational administration. Higher vocational teaching operation and management should pay attention to: in the classroom teaching, different levels (education level, skills level) of the teaching object of teaching organization and implementation, focusing on clever use of teaching methods; class, class, exam and other teaching links running coherence, Improve the credit system; mobilize all available resources, organize internal and external practice teaching, flexible operation performance assessment methods. In the educational administration, educational administration management mainly refers to the school, secondary college, teaching department (campus) and other teaching management departments should be based on teaching rules and school rules and regulations to exercise management authority, the teaching activities and related auxiliary work scientific and reasonable Of the organization, command, scheduling, to ensure the school teaching work in a stable and orderly operation of the coordination process, of course, including strict and standardized to do the daily management of teaching, school management and teaching file management. Merging and upgrading of higher vocational colleges in the teaching of administrative work is more severe, such as the need to ensure that before the merger of the school teaching materials, student files archiving, so no omissions, the establishment of a complete system.

The basic point of teaching management is through the coordination of standardized management to maintain a stable operation of teaching work to ensure the quality of teaching. Teaching quality management is the core of the teaching management system, improve the quality of teaching is an eternal theme of the school. The survival of higher vocational institutions is the "quality", good quality of teaching in order to cultivate good quality graduates. Teaching is to train people's activities, the evaluation of the quality of talent is very complex, and because the teaching process time span is relatively large, the effect is not by the immediate or recent indicators to measure. The quality of teaching is a comprehensive concept that is influenced by many elements, including teachers, students, managers, equipment and funds. It is the sum of the indicators after the comprehensive operation of the complex teaching process. However, the teaching activities or regular, vocational colleges can establish a complete set of quality assurance system, so timely 
monitoring. Teaching quality assurance system includes quality assurance institutions, systems, strategies and monitoring feedback.

\section{Reform and Innovation of Teaching Management}

The reform and innovation of teaching management in higher vocational colleges must first be based on the idea of changing education and establishing the modern educational concept as the forerunner and the driving force. The modernity of higher vocational colleges is mainly reflected in the conditions of running schools, school management, quality of education, quality of personnel, etc., of which management is the key. The "scientific development concept" proposed by the state is the development concept of the subject and the object, the unity of man and nature, and the unity of quality and quantity of development. Emphasize the all-round development, harmonious development and multidimensional development, and emphasize people's core and people-oriented. The scientific development concept provides a strong theoretical basis for the reform of education and teaching management, which is of great significance to the reform and development of higher vocational education.

School development of teaching management rules and regulations and teaching management process should first take into account the "people", that is, taking into account the teachers and students, respect for teachers and students of the individual, respect for the law of education to meet the needs of teachers and students, more consideration of human care The People-centered, full respect for people, understand people, care about people, to mobilize the enthusiasm of people, pay more attention to democratic management, decision-making scientific and management effectiveness. At present, an important orientation of higher vocational education at home and abroad is the concept of "sustainable development". Focusing on sustainable development, putting values, skills and attitudes into the construction and development of higher vocational education. The reform of teaching management in higher vocational colleges is the focus and difficulty of school development, and it is necessary to introduce the concept of sustainable development. Establish a mechanism to adapt to the development of the situation to achieve continuous adjustment, in order to achieve the overall efficiency of management goals.

The teaching management of modern education should keep pace with the times, always maintain a certain degree of advanced nature, constantly update the management of the content, reform management methods, improve the management means, with the characteristics of modern times. Correctly handle the relationship between the internationalization of teaching management and the localization characteristics, update the quality standards, establish a standard system that conforms to the national conditions and the school situation and conforms to the international standard, according to the international rules, and pay attention to the development advantages and keep the characteristics.

In order to accelerate the substantive integration of the individual organizations and promote the leap-forward development of the schools, it is necessary to carry out comprehensive reform and innovation of the teaching management system. At present, there are four kinds of basic management modes existing in the university, namely, the three-level management mode of the school and the hospital. The school management system, the school-level management system, Management mode. Combined with the scale and characteristics of higher vocational colleges, we must first establish a suitable management system model for the development of the school, and then from the perspective of discipline development, personnel training, management innovation, school efficiency perspective, and gradually promote the overall reform of the teaching system.

Teaching management rules and regulations are the teaching and learning ideas, teaching management guiding ideology and habitual management of the form of expression. Sound rules and regulations, in line with the inherent requirements of education and management science and management, is conducive to the establishment of standardized teaching order, is conducive to mobilize teaching, learning, management and other aspects of the initiative, is conducive to advancing teaching reform, is conducive to improving the quality of personnel training. Establish and improve the teaching management of the rules and regulations, the development of various 
teaching aspects of the regulatory requirements, so that the school teaching management rules to follow, according to the law, the strict management throughout the entire process of personnel training.

The teaching management system of multi-layer ring, interlocking, close structure and function optimization is constructed. Through the system "loop, cycle", we should pay attention to the design, inspection, monitoring, evaluation and feedback function of education and teaching management. Management of the teaching quality of the monitoring, protection and guidance of student learning function, to strengthen the teaching evaluation in teaching management in the incentive, guiding role. According to the functional requirements of teaching management, according to the point of view of cybernetics, this teaching management system should include four subsystems: teaching work decision, implementation, monitoring, communication and feedback.

The teaching activities of colleges and universities are a kind of intellectual high-level activities. At the same time, the participants, teachers and students of teaching activities have higher quality. Therefore, the teaching management can not be strictly pursued, but should be used strictly at the same time. Incentive mechanism to mobilize the enthusiasm and consciousness of teachers and students. To improve and improve the teaching effectiveness evaluation system, excellent teaching (including practical teaching) reward system, etc., to encourage teachers to actively teach and make more achievements in teaching; to establish a good student reward system, scholarship system, personal expertise (including Design, production, invention, creation, etc.) incentive system, to stimulate students 'potential enthusiasm for learning, training students' innovative consciousness and innovative spirit. This is from the heart of the teaching and learning generated spontaneous power, fundamentally improve the quality and efficiency of teaching management.

\section{Conclusion}

The reform of teaching management in higher vocational colleges is a close combination of theory and practice. Both the need for theoretical innovation, but also have a strong system and practical. As many vocational colleges have been established in recent years, teaching management mechanism is very imperfect. Is basically copy the copy of the undergraduate teaching management model. Teaching Management Urgently Reform and Innovation. And I have been working in the school's teaching management office for many years, although every day facing a tedious work, but deeply teaching management responsibility: how to really improve the quality of teaching management, how to change the status of teaching management, how to science The introduction of educational ideas to enhance the level of teaching management, and how to achieve the teaching management process innovation and so on such issues arouse my interest. Is based on this, as a topic of my thesis. In the course of this research, I deeply feel that teaching management is a very complex integrated system. The reform of teaching management should focus on the reform of personnel training mode. And school teaching reform in sync with the leadership system, personnel system and so on. The research content is very rich, involving a wide range of work is very large, at the same time, teaching management practice is strong, and the school discipline professional characteristics and their own traditions are closely related, research and practice closely, to have a strong Targeted and operable.

\section{References}

[1] Zhu Wen, Zhang Hu. Evolution and evaluation of the internationalization policy support system of higher education [J]. Journal of Education, Education and Management.

[2] Shen Hui. Bloomberg "Higher Education Philosophy" related research summary [J]. Modern communication.

[3] Wei Fang. Tai Si Zheng from the perspective of ideological and political education teaching reform methods and path [J]. Modern communication.

[4] Pangxiao $\mathrm{Xu}$. On the improvement of college students party members ideological and political 
quality of the countermeasures [J]. Modern communication.

[5] Han Zhiying. Office automation analysis to promote the Jilin University computer grade examination reform [J]. Modern communication. 